\title{
BIOLOGICAL INTEGRITY OF JACKSON CREEK, JENNIES FORK, AND GRANITE CREEK IN THE LAKE HELENA TMDL PLANNING AREA BASED ON THE STRUCTURE AND COMPOSITION OF THE BENTHIC ALGAE COMMUNITY
}

\author{
Prepared for: \\ State of Montana \\ Department of Environmental Quality \\ P.O. Box 200901 \\ Helena, Montana 59620-0901 \\ Project Officer: Alan Nixon \\ DEQ Contract No. 200012-8
}

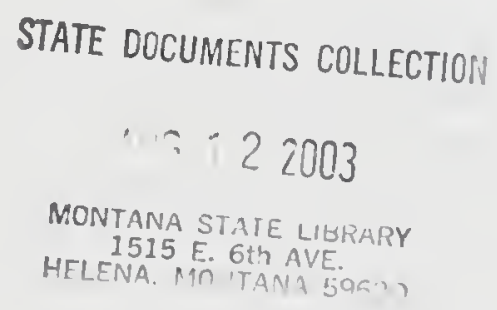

\author{
Prepared by: \\ Loren L. Bahls, Ph.D. \\ Hannaea \\ 1032 Twelfth Avenue \\ Helena, Montana 59601
}

June 23, 2003

Printed on Paper Madc from 100\% Recycled Post-Consumer Fiber 
-

-

중 


\section{Summary}

In August 2002, periphyton samples were collected from Jackson Creek, Jennies Fork, and Granite Creek in the Lake Helena TMDL planning area in west central Montana for the purpose of assessing whether these streams are water-quality limited and in need of TMDLs. The samples were collected following MDEQ standard operating procedures, processed and analyzed using standard methods for periphyton, and evaluated following modified USEPA rapid bioassessment protocols for wadeable streams.

A large number of motile diatoms in Jackson Creek indicate moderate impairment from sedimentation and only partial support of aquatic life uses. The pollution-tolerant bluegreen alga Oscillatoria was abundant and ranked first in biovolume in Jackson Creek. The pollution index here indicated minor impairment and somewhat elevated organic loading for a mountain stream. In addition, a larger than normal number of teratological diatom cells may indicate chronic toxicity from elevated heavy metals at this site.

Hydrurus foetidus was the most abundant alga in Jennies Fork. This cold-water stenotherm thrives in flashy mountain streams that have unstable channels and exhibit wide seasonal fluctuations in flow, temperature, and turbidity. A large number of Achnanthidium minutissimum in Jennies Fork indicates minor stress from natural scour. The pollution index and the sedimentation index indicate minor impairment from organic loading and sedimentation, respectively. Four teratological diatom cells were recorded at this site, which may indicate low background levels of heavy metals.

Granite Creek had the best biological integrity of the three sites, although both the pollution index and the sedimentation index approached their respective thresholds for minor impairment. The filamentous green alga Cladophora was abundant in Granite Creek. Streams that support large stands of filamentous algae typically have more stable flows, firmer substrates, and larger concentrations of inorganic nutrients than streams that do not support these algae. The presence of Nostoc in Granite Creek indicates that nitrogen was likely the limiting nutrient at this site. Unlike Jackson Creek and Jennies Fork, where most diatoms require continuously high levels of dissolved oxygen and tolerate variable concentrations of inorganic nutrients, most diatoms in Granite Creek require only moderate levels of dissolved oxygen and indicate eutrophic conditions. 


\section{Introduction}

This report evaluates the biological integrity ${ }^{1}$, support of aquatic life uses, and probable causes of stress or impairment to aquatic communities in Jackson Creek, Jennies Fork, and Granite Creek in the Lake Helena TMDL planning area in west central Montana. The purpose of this report is to provide information that will help the State of Montana determine whether these streams are water-quality limited and in need of TMDLs.

The federal Clean Water Act directs states to develop water pollution control plans (Total Maximum Daily Loads or TMDLs) that set limits on pollution loading to water-quality limited waters. Water-quality limited waters are lakes and stream segments that do not meet waterquality standards, that is, that do not fully support their beneficial uses. The Clean Water Act and USEPA regulations require each state to (1) identify waters that are water-quality limited, (2) prioritize and target waters for TMDLs, and (3) develop TMDL plans to attain and maintain water-quality standards for all water-quality limited waters.

Evaluation of aquatic life use support in this report is based on the species composition and structure of periphyton (aka benthic algae, phytobenthos) communities at three sites that were sampled in August of 2002. Periphyton is a diverse assortment of simple photosynthetic organisms called algae that live attached to or in close proximity of the stream bottom. Some algae form long filaments or large gelatinous colonies that are conspicuous to the unaided eye. But most algae, including the ubiquitous diatoms, can be seen and identified only with the aid of a microscope. The periphyton community is a basic biological component of all aquatic ecosystems. Periphyton accounts for much of the primary production and genetic diversity in Montana streams (Bahls et al. 1992). Plafkin et al. (1989) and Barbour et al. (1999) list several advantages of using periphyton in biological assessments.

\footnotetext{
${ }^{1}$ Biological integrity is defined as "the ability of an aquatic ecosystem to support and maintain a balanced, integrated, adaptive community of organisms having a species composition, diversity, and functional organization comparable to that of natural habitats within a region" (Karr and Dudley 1981).
} 


\section{Project Area and Sampling Sites}

The project area is located within Level IV ecoregion $15 \mathrm{f}$ (Eastern Divide Mountains), which is a part of the Northern Rockies Ecoregion in Lewis and Clark and Jefferson Counties, Montana (Woods et al. 1999). This is a semiarid to sub-humid, largely forested region east of the Continental Divide that is underlain by Precambrian Belt formations. The Eastern Divide Mountains receive 12 to 25 inches of precipitation per year. The climax vegetation consists of Douglas-fir and ponderosa pine forests, with subalpine fir occurring at the highest elevations. The main land uses are logging, mining, recreation, and wildlife habitat.

Periphyton samples were collected at one site each on Jackson Creek, Jennies Fork, and Granite Creek (Table 1, Maps 1-3). All three streams are in upper Missouri River hydrologic unit (USGS HUC 10030101). Jackson Creek is a tributary of McClellan Creek, which joins Prickly Pear Creek near Montana City. Jennies Fork is a tributary of Silver Creek, which flows into Lake Helena. Granite Creek is a tributary of Austin Creek, which is a tributary of Greenhorn Creek, which is a tributary of Sevenmile Creek. Sevenmile Creek joins Tenmile Creek northwest of Helena and Tenmile Creek joins Prickly Pear Creek just above Lake Helena. All three streams are classified B-1 in the Montana Surface Water Quality Standards. Elevations at the sampling sites range from about 5,000 feet at the mouth of Jackson Creek to 5,840 feet at Jennies Fork downstream of the parking area for Great Divide Snowsports.

\section{Methods}

Periphyton samples were collected following standard operating procedures of the MDEQ Planning, Prevention, and Assistance Division. Using appropriate tools, microalgae were scraped, brushed, or sucked from natural substrates in proportion to the importance of those substrates at each study site. Macroalgae were picked by hand in proportion to their abundance at the sitc. All collections of microalgae and macroalgae were pooled into a common container and preserved with Lugol's (IKI) solution. 
The samples were examined to estimate the relative abundance and rank by biovolume of diatoms and genera of soft (non-diatom) algae according to the method described in Bahls (1993). Soft algae were identified using Smith (1950), Prescott (1962, 1978), John et al. (2002), and Wehr and Sheath (2003). These books also served as references on the ecology of the soft algae, along with Palmer (1969, 1977).

After the identification of soft algae, the raw periphyton samples were cleaned of organic matter using sulfuric acid, potassium dichromate, and hydrogen peroxide. Then permanent diatom slides were prepared using Naphrax, a high refractive index mounting medium, following Standard Methods for the Examination of Water and Wastewater (APHA 1998). At least 400 diatom cells ( 800 valves) were counted at random and identified to species. The following were the main taxonomic references for the diatoms: Krammer and Lange-Bertalot 1986, 1988, 1991 a, 1991b; Lange-Bertalot 1993, 2001; Krammer 1997a, 1997b, 2002; Reichardt 1997, 1999. Diatom naming conventions followed those adopted by the Academy of Natural Sciences for USGS NAWQA samples (Morales and Potapova 2000) as updated in 2003 (Dr. Eduardo Morales, Academy of Natural Sciences, digital communication). Van Dam et al. (1994) was the main ecological reference for the diatoms.

The diatom proportional counts were used to generate an array of diatom association metrics. A metric is a characteristic of the biota that changes in some predictable way with increased human influence (Barbour et al. 1999). Diatoms are particularly useful in generating metrics because there is a wealth of information available in the literature regarding the pollution tolerances and water quality preferences of common diatom species (e.g., Lowe 1974, Beaver 1981, Lange-Bertalot 1996, Van Dam et al. 1994).

Values for selected metrics were compared to biocriteria (numeric thresholds) developed for streams in the Recky Mountain ecoregions of Montana (Table 2). These criteria are based on metric values measured in least-impaired reference streams (Bahls et al. 1992) and metric values measured in streams that are known to be impaired by various sources and causes of pollution (Bahls 1993). The criteria in Table 2 are valid only for samples collected during the summer field season (June 21 -September 21) and distinguish among four levels of stress or impairment 
and three levels of aquatic life use support: (1) no impairment or only minor impairment (full support); (2) moderate impairment (partial support); and (3) scvere impairment (nonsupport). These impairment levels correspond to excellent, good, fair, and poor biological integrity, respectively. In cold, high-gradient mountain strearns, natural stressors will often mimic the effects of man-caused impairment on some metric values.

\section{Quality Assurance}

Several steps were taken to assure that the study results are accurate and reproducible. Upon receipt of the samples, station and sample attribute data were recorded in the Montana Diatom Database and the samples were assigned a unique number, e.g., 2664-01. The first part of this number (2664) designates the sampling site (Jackson Creek near mouth) and the second part (01) designates the number of periphyton samples that that have been collected at this site for which data have been entered into the Montana Diatom Database.

Sample observations and analyses of soft (non-diatom) algae were recorded in a lab notebook along with information on the sample label. A portion of the raw sample was used to make duplicate diatom slides. The slides used for the diatom proportional counts will be deposited in the Montana Diatom Collection at the University of Montana Herbarium in Missoula. The duplicate slides will be retained by Hannaea in Helena. Diatom proportional counts have been entered into the Montana Diatom Database.

\section{Results and Discussion}

Results are presented in Tables 3,4 and 5, which are located near the end of this report following the references section. Copies of aquatic plant field sheets are included in Appendix A. Appendix B contains a diatom report for each sample. Each diatom report includes an alphabetical list of diatom species in that sample and their percent abundances, and values for 65 different diatom metrics and ecological attributes. 


\section{Sample Notes}

Jackson Creek. Teratological cells of the diatom Synedra ulna were observed during the scan of soft algae.

Jennies Fork. The sample from this site was silty.

Granite Creek. The sample from this site contained moss. An ear-shaped colony of Nostoc parmelioides was present in this sample. The morphology of colonies of Nostoc parmelioides, a filamentous cyanobacterium common in mountain streams, is altered from spherical to ear-shaped by the presence of an endosymbiotic midge larva. Ear-shaped colonies exhibit greater photosynthesis and nitrogen-fixation rates in response to higher current velocities, while spherical colonies do not respond in this manner (Wehr and Sheath 2003).

\section{Non-Diatom Algae (Table 3)}

Diatoms and cyanobacteria, including Oscillatoria sp., were present at all three sites. The chrysophyte Hydrurus foetidus was present only in Jennies Fork and red and green algae (Rhodophyta and Chlorophyta) were present only in Granite Creek (Table 3).

Jackson Creek. The filamentous blue-green alga Oscillatoria was abundant and ranked first in biovolume in the sample from Jackson Creek (Table 3). Oscillatoria includes almost 70 species and typically grows in mats on different substrata (mud, plants, stones, sand) in shallow water. Taking all species into account, Palmer (1969) ranks Oscillatoria second, next only to Euglena, in terms of tolerance to organic loading. Diatoms were frequent and ranked $2^{\text {nd }}$ in biovolume here, followed by Nostoc, which was common and ranked $3^{\text {rd }}$. This site supported only 2 genera of non-diatom algae, both of them blue-greens.

Jennies Fork. Hydrurus foetidus was abundant and ranked first in biovolume in Jennies Fork (Table 3). Nicholls and Wujek (2003) reviewed the biology of this common alga: 
One of the most dramatic cxamples of a cold-water stenotherm is the mountainstream-dwelling chrysophyte Hydrurus foetidus. This macroscopic, brown, gelatinous, unpleasant-smelling alga is relatively abundant in both the eastern and western mountain streams of North America. The gelatinous envelope in which the cells are embedded is exceedingly tough and the plant frequently covers the entirc surface of submerged rocks and has caused more than one hiker to lose his or her footing when crossing a stream. It normally begins to disappear when water temperatures rise much above $10^{\circ} \mathrm{C} \ldots$ Other requirements for this species apparently include low $\mathrm{pH}$ and bright sunlight.

Hydrurus foetidus often dominates the winter and spring algal communities of glacier-fed streams of the Swiss Alps, which exhibit unstable channels and wide seasonal fluctuations in flow, temperature, and turbidity (Hieber et al. 2001). Elsewhere, Kawecka (1990) reported that Hydrurus foetidus dominated the algal communities of unregulated streams in a study of paired regulated and unregulated streams.

Diatoms were common in Jennies Fork and ranked $2^{\text {nd }}$, while Oscillatoria sp. was occasional and ranked $3^{\text {rd }}$. Like Jackson Creek, Jennies Fork supported only 2 genera of nondiatom algae (Table 3$)$.

Granite Creek. The filamentous green alga Cladophora was abundant and ranked $1^{\text {st }}$ in biovolume in Granite Creek (Table 3). Streams that support large amounts of filamentous algae typically have more stable flows, firmer substrates, and larger concentrations of inorganic nutrients than streams that do not support these algae. Diatoms were frequent and ranked $2^{\text {nd }}$ in biovolume here, followed by Nostoc (frequent) and the desmid Cosmarium (common). This site supported at least 5 genera of non-diatom algae, including occasional cells of Oscillatoria and the filamentous red alga Audouinella.

The presence of Nostoc in Granite Creek, especially ear-shaped colonies of Nostoc parmelioides (see discussion under Sample Notes above), indicates that nitrogen was likely the limiting nutrient at this sitc. Large stands of filamentous macroalgae (e.g., Cladophora) arc known to release surplus $\mathrm{PO}_{4}$ into the ambient water, thereby decreasing the local N:P ratio and conferring a competitive advantage on nitrogen-fixing algae, such as heterocyst-bearing bluegreen algae (e.g., Nostoc) (Lowe 2003). 


\section{Diatoms (Table 4)}

The eight major diatom species from Jackson Creek, Jernies Fork, and Granite Creek are included in pollution tolerance classes 3 or 2 and are either sensitive to organic pollution or only somewhat tolerant of organic pollution (Table 4). None of the major diatom species are most tolerant of organic pollution (pollution tolerance class $=1$ ).

Jackson Creek. A large number of motile diatoms in the sample from Jackson Creek indicate moderate impairment from sedimentation and only partial support of aquatic life uses at this site (Table 4). The pollution index here was below the threshold for minor impairment, indicating somewhat elevated organic loading for a mountain stream. In addition, a larger than normal number of teratological diatom cells may indicate chronic toxicity from elevated heavy metals at this site. Sometimes rapidly growing populations of diatoms will produce abnormal cells when silica is limiting. However, teratological cells were recorded for six different species in Jackson Creek, including five minor species that did not have large populations and were not evidently in a rapid growth phase.

Except for Achnanthidium minutissimum, which is sensitive, the major diatom species in Jackson Creek are somewhat tolerant of organic pollution. Two of these species-Navicula cryptotenella and Nitzschia linearis - are motile and adapted to living on shifting substrates of fine sediment. The remaining major species-Planothidium lanceolatum (=Achnanthes lanceolata) - is an adnate, non-motile species that is adapted to living on sand grains.

Jennies Fork. Achnanthidium minutissimum was the dominant diatom species in Jennies Fork (Table 4). Large numbers of this adnate pioneer species indicates a high level of physical, chemical, or biological disturbance in the form of scour, metals toxicity, or invertebrate grazing, respectively. The abundance of Hydrurus foetidus at this site (see discussion above under NonDiatom Algae) indicates that physical scour is the most likely cause of disturbance in Jennies Fork. The large number of $A$. minutissimum indicates minor stress from natural scour. 
The pollution index and the siltation index indicate minor impairment in Jennies Fork from organic loading and sedimentation, respectively. Aside from A. minutissimum, the only major diatom species recorded here were Fragilaria vaucheria, which is somewhat tolerant of organic pollution, and Planothidium lanceolatum, which is both somewhat tolerant of organic pollution and adapted to living on sand grains. Four teratological diatom cells were also recorded at this site, which may indicate low background levels of heavy metals.

Granite Creek. Granite Creek exhibited the best biological integrity of the three sites, although both the pollution index and the siltation index approached their respective thresholds for minor impairment (Table 4). The dominant diatom species here was Cocconeis placentula, which, like $A$. minutissimum, is a pioneer adnate species adapted to living on hard substrates (cobbles and coarse sand).

Gomphonema rhombicum was also a major diatom species in Granite Creek. This species is sensitive to organic pollution and grows on stalks that elevate the cells above the understory layer of attached algae (e.g., Cocconeis placentula). An abundance of Gomphonema, along with the abundance of Cladophora here, indicates a stable, mature periphyton community. Another major species here was Rhoicosphenia abbreviata (=Rhoicosphenia curvata), which is also sensitive to organic pollution and, like G. rhombicum, requires firm substrates for attachment. The other major species here were Fragilaria vaucheriae (somewhat tolerant of organic pollution) and Planothidium lanceolatum (pollution tolerant and adapted to living on sand grains). Only one teratological diatom cell (of Fragilaria vaucheriae) was recorded in Granite Creek.

\section{Modal Categories (Table 5)}

Several ecological attributes assigned by Stevenson and Van Dam et al. (1994) were selected from the diatom reports in the appendix and modal categories of these attributes were extracted to characterize water quality tendencies in Jennies Fork and in Jackson and Granite Creeks (Table 5). 
Most diatoms at all three sites were non-motile autotrophs that tolerate high levels of organic nutrients and indicate fresh waters with low to moderate levels of BOD (Table 5). While most diatoms in Jackson Creek and Granite Creek are alkaliphilous and prefer pH levels above 7.0, most diatoms in Jennies Fork prefer somewhat lower pH levels (around 7.0). In Granite Creek, most diatoms exert only a moderate demand for dissolved oxygen, whereas most diatoms in Jackson Creek and Jennies Fork exert a continuously high demand for dissolved oxygen. Also, most diatoms in Granite Creek indicate eutrophic conditions, while most diatoms in Jackson Creek and Jennies Fork tolerate a wide range of trophic conditions from oligotrophic to eutrophic.

\section{References}

APHA. 1998. Standard Methods for the Examination of Water and Wastewater. 20 Edition. American Public Health Association, Washington, D.C.

Bahls, L.L. 1979. Benthic diatom diversity as a measure of water quality. Proceedings of the Montana Academy of Sciences 38:1-6.

Bahls, L.L. 1993. Periphyton Bioassessment Methods for Montana Streams (revised). Montana Department of Health and Environmental Sciences, Helena.

Bahis, L.L., Bob Bukantis, and Steve Tralles. 1992. Benchmark Biology of Montana Reference Streams. Montana Department of Health and Environmental Sciences, Helena.

Barbour, M.T., J. Gerritsen, B.D. Snyder, and J.B. Stribling. 1999. Rapid Bioassessment Protocols for Use In Streams and Wadeable Rivers: Periphyton, Benthic Macroinvertebrates and Fish. Second Edition.

EPA/841-B-99-002. U.S. Environmental Protection Agency, Office of Water, Washington, D.C.

Beaver, Janet. 1981. Apparent Ecological Characteristics of Some Common Freshwater Diatoms. Ontario Ministry of The Environment, Technical Support Section, Don Mills, Ontario.

Hieber, Maggi, C.T. Robinson, S. R. Rushforth, and Urs Uehlinger. 2001. Algal communities associated with different alpine stream types. Arctic, Antarctic, and Alpine Research 33(4):447-456.

Johansen, J.R. 1999. Diatoms of Aerial Habitats. Chapter 12 in Stoermer, E.F., and J.P. Smol (eds.), The Diatoms: Applications For the Environmental and Earth Sciences, Cambridge University Press, New York.

John, D.M., B.A. Whitton, and A.J. Brook (eds.). 2002. The Freshwater Algal Flora of the British Isles: An Identification Guide to Freshwater and Terrestrial Algae. Cambridge University

Kan, J.R., and D.R. Dudley. 1981. Ecological perspectives on water quality goals. Environmental Management 5:55-69. 
Kawecka, B. 1990. The effect of flood-control regulation of a montane stream on the communities of sessile algae. Acta Hydrobiology 32:345-354.

Krammer, Kurt. 1997a. Die cymbelloiden Diatomeen: Eine Monographie der weltweit bekannten Taxa. Teil 1. Allgemeines and Encyonema Part. J. Cramer, Berlin.

Krammer, Kurt. 1997b. Die cymbelloiden Diatomeen: Eine Monographie der weltweit bekannten Taxa. Teil 2. Encyonema part., Encyonopsis and Cymbellopsis. J. Cramer, Berlin.

Krammer, Kurt. 2002. Cymbella. Volume 3 in Diatoms of Europe, Horst Lange-Bertalot, ed. A.R.G. Gantner Verlag K.G., Germany.

Krammer, K., and H. Lange-Bertalot. 1986. Bacillariophyceae, Part 2, Volume I: Naviculaceae. In Ettl, H., J Gerloff, H. Heynig, and D. Mollenhauer (eds.), Freshwater Flora of Middle Europe. Gustav Fischer Publisher, New York.

Krammer, K., and H. Lange-Bertalot. 1988. Bacillariophyceae, Part 2, Volume 2: Bacillariaceae, Epithemiaceae, Surirellaceae. In Ettl, H., J. Gerloff, H. Heynig, and D. Mollenhauer (eds.), Freshwater Flora of Middle Europe. Gustav Fischer Publisher, New York.

Krammer, K., and H. Lange-Bertalot. 1991a. Bacillariophyceae, Part 2, Volume 3: Centrales, Fragilariaceae, Eunotiaceae. In Ettl, H., J. Gerloff, H. Heynig, and D. Mollenhauer (eds.), Freshwater Flora of Middle Europe. Gustav Fischer Publisher, Stuttgart.

Krammer, K., and H. Lange-Bertalot. 1991b. Bacillariophyceae, Part 2, Volume 4: Achnanthaceae, Critical Supplement to Navicula (Lineolatae) and Gomphonema, Complete List of Literature for Volumes 1-4. In Ettl, H., G. Gartner, J. Gerloff, H. Heynig, and D. Mollenhauer (eds.), Freshwater Flora of Middle Europe. Gustav Fischer Publisher, Stuttgart.

Lange-Bertalot, Horst. 1979. Pollution tolerance of diatoms as a criterion for water quality estimation. Nova Hedwigia 64:285-304.

Lange-Bertalot, Horst. 1993. 85 new taxa and much more than 100 taxonomic clarifications supplementary to Susswasserflora von Mitteleuropa Vol. 2/1-4. J. Cramer, Berlin.

Lange-Bertalot, Horst. 1996. Rote Liste der limnischen Kieselalgen (Bacillariophyceae) Deutschlands. Schr.-R. f. Vegetationskde., H. 28, pp. 633-677. BfN, Bonn-Bad Godesberg.

Lange-Bertalot, Horst. 2001. Navicula sensu stricto: 10 Genera Separated from Navicula sensu lato; Frustulia. Volume 2 in Diatoms of Europe, Horst Lange-Bertalot, ed. A.R.G. Gantner Verlag K.G., Germany.

Lowe, R.L. 1974. Environmental Requirements and Pollution Tolerance of Freshwater Diatoms. EPA-670/4-74-005. U.S. Environmental Protection Agency, National Environmental Research Center, Office of Research and Development, Cincinnati, Ohio.

Lowe, R.L. 2003. Keeled and Canalled Raphid Diatoms. Chapter 19 in Wehr, J.D., and R.G. Sheath (eds.), Freshwater Algae of North America: Ecology and Classification. Academic Press, New York. 918 pp.

McFarland, B.H., B.H. Hill, and W.T. Willingham. 1997. Abnormal Fragilaria spp. (Bacillariophyceae) In streams impacted by mine drainage. Journal of Freshwater Ecology 12(1):141-149.

Morales, E.A., and Marina Potapova. 2000. Third NAWQA Workshop on Harmonization of Algal Taxonomy, May 2000. Patrick Center for Environmental Research, The Academy of Natural Sciences, Philadelphia.

Nicholls, K.H., and D.E.Wujek. 2003. Chrysophycean Algae. Chapter 12 (pp. 471-509) in Wehr, J.D., and R.G. Sheath (eds.), Freshwater Algae of North America: Ecology and Classification. Academic Press, New York. 
Palmer, C.M. 1969. A composite rating of algae tolerating organic pollution. Journal of Phycology 5:78-82.

Palmer, C.M. 1977. Algae and Water Pollution: An lllustrated Manual on the Identification, Significance, and Control of Algae in Water Supplies and in Polluted Water. EPA-600/9-77-036.

Plafkin, J.L., M.T. Barbour, K.D. Porter, S.K. Gross, and R.M. Hughes. 1989. Rapid Bioassessment Protocols for Use in Rivers and Streams: Benthic Macroinvertebrates and Fish. EPA 440-4-89-001.

Prescott, G.W. 1962. Algae of the Western Great Lakes Area. Wm. C. Brown Company, Dubuque, lowa.

Prescott, G.W. 1978. How to Know the Freshwater Algae. Third Edition. Wm. C. Brown Company Publishers, Dubuque, Iowa.

Reichardt, Erwin. 1997. Taxonomische Revision des Artenkomplexes um Gomphonema pumilum (Bacillariophyta). Nova Hedwigia 65(1-4):99-129.

Reichardt, Erwin. 1999. Zur Revision der Gattung Gomphonema. A.R.G. Gantner Verlag, Distributed by Koeltz Scientific Books, Konigstein, Germany.

Renfro, H.B., and D.E. Feray. 1972. Geological Highway Map of the Northern Rocky Mountain Region. American Association of Petroleum Geologists, Tulsa, Oklahoma.

Smith, G.M. 1950. The Fresh-Water Algae of The United States. McGraw-Hill Book Company, New York.

Stevenson, R.J., and Y. Pan. 1999. Assessing Environmental Conditions in Rivers and Streams with Diatoms. Chapter 2 in Stoermer, E.F., and J.P. Smol (eds.), The Diatoms: Applications For the Environmental and Earth Sciences, Cambridge University Press, New York.

Stewart, W.D.P., P. Rowell, and A.N. Rai. 1980. Symbiotic Nitrogen-Fixing Cyanobacteria. Pp. 239-277 in Stewart, W.D.P., and J. Gallo (eds.), Nitrogen Fixation, Academic Press, New York.

USDA. 1976. Climax Vegetation of Montana (map). U.S. Department of Agriculture, Soil Conservation Service, Cartographic Unit, Portland.

USEPA. 2000. Level I1I Ecoregions of the Continental United States (map). National Health and Environmental Effects Research Laboratory, U.S. Environmental Protection Agency, Corvallis, Oregon.

Van Dam, Herman, Adrienne Mertens, and Jos Sinkeldam. 1994. A coded checklist and ecological Indicator values of freshwater diatoms from The Netherlands. Netherlands Journal of Aquatic Ecology 28(1):117-133.

Weber, C.I. (ed.). 1973. Biological Field and Laboratory Methods for Measuring the Quality of Surface Waters and Effluents. EPA-670/4-73-001. U.S. Environmental Protection Agency, National Environmental Research Center, Office of Research and Development, Cincinnati, Ohio.

Wehr, J.D., and R.G. Sheath. 2003. Freshwater Algae of North America: Ecology and Classification. Academic Press, New York.

Whittaker, R.H. 1952. A study of summer foliage insect communities in the Great Smoky Mountains. Ecological Monographs 22:1-44.

Woods, A.J., Omernik, J.M., Nesser, J.A., Shelden, J., and S.H. Azevedo. 1999. Ecoregions of Montana (color poster with map), U.S. Geological Survey, Reston, Virginia. 


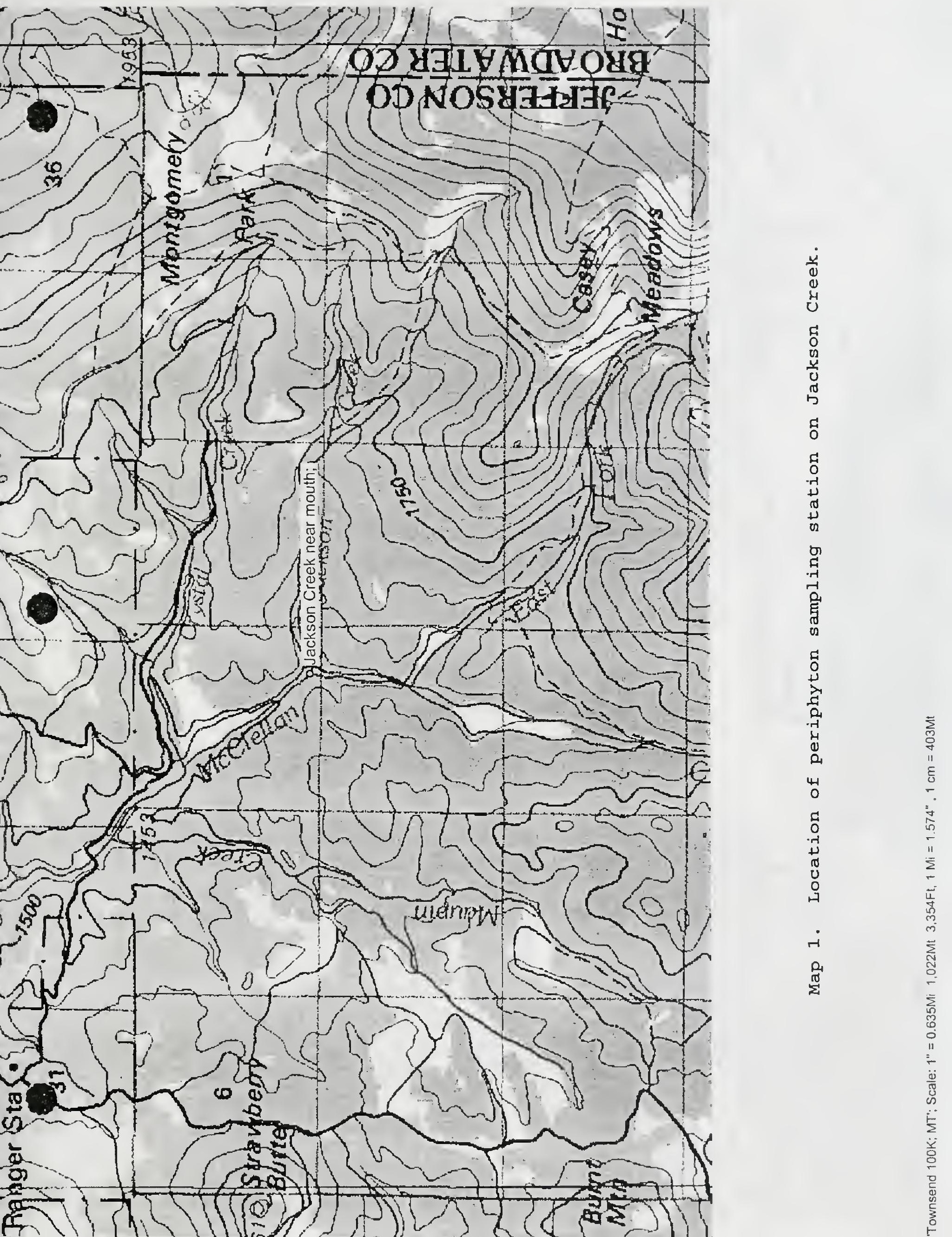




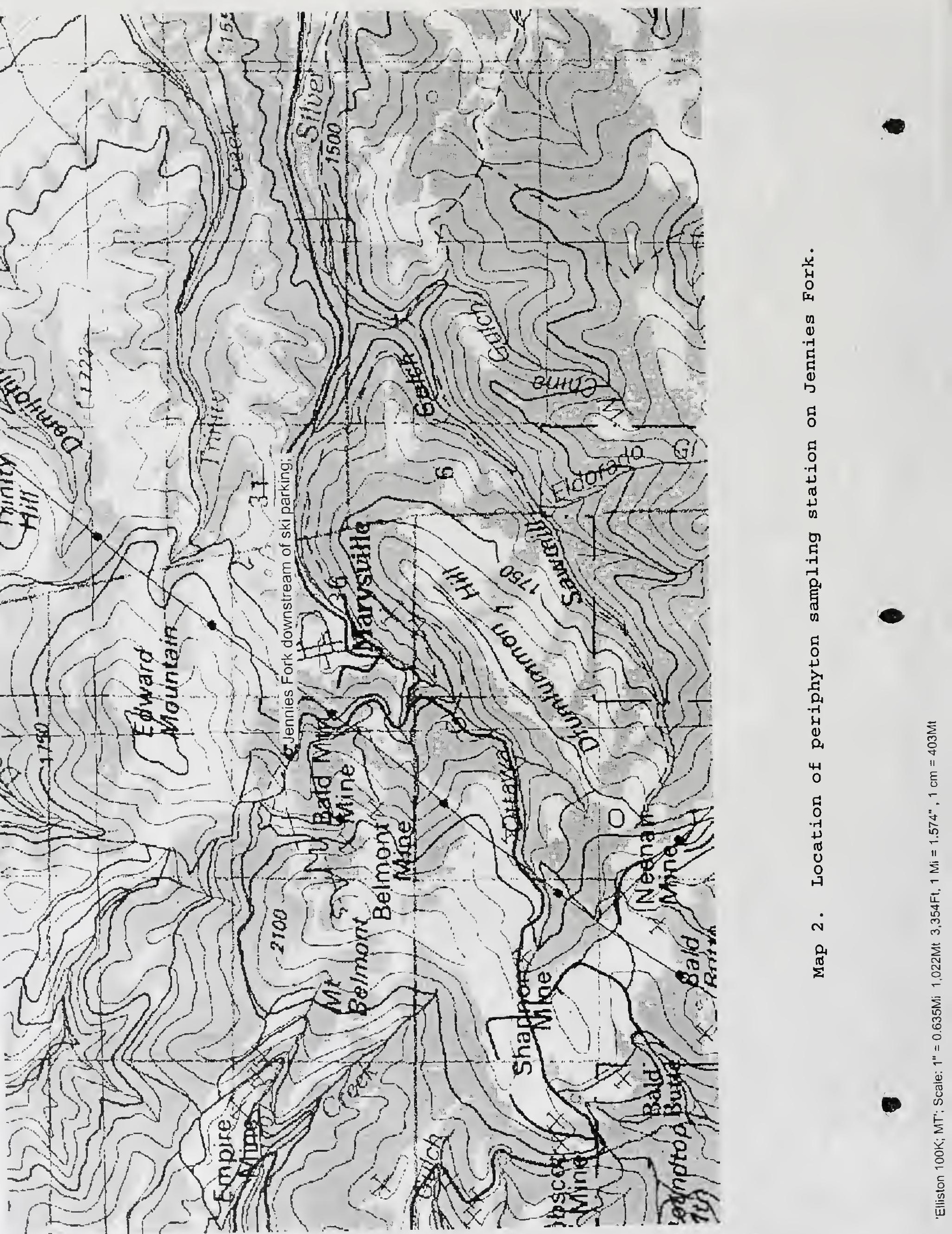


Table 1. Location of periphyton sampling stations in the Lake Helena TMDL planning area, 2002.

\begin{tabular}{lccccc}
\hline \multicolumn{1}{c}{ Station } & $\begin{array}{c}\text { MDEQ } \\
\text { Station } \\
\text { Code }\end{array}$ & $\begin{array}{c}\text { Hannaea } \\
\text { Sample } \\
\text { Number }\end{array}$ & Latitude & Longitude & $\begin{array}{c}\text { Sample } \\
\text { Date }\end{array}$ \\
\hline Jackson Creek near mouth & M09JCKSC02 & $2664-01$ & $46-28-18.5$ & $111-51-10.4$ & $9 / 11 / 02$ \\
Jennies Fork downstream of ski parking & M09JENYF02 & $2665-01$ & $46-45-09.2$ & $112-18-40.8$ & $9 / 11 / 02$ \\
Granite Creek near mouth & M09GRNTC01 & $2666-01$ & $46-38-27.4$ & $112-17-09.8$ & $9 / 11 / 02$ \\
\hline
\end{tabular}




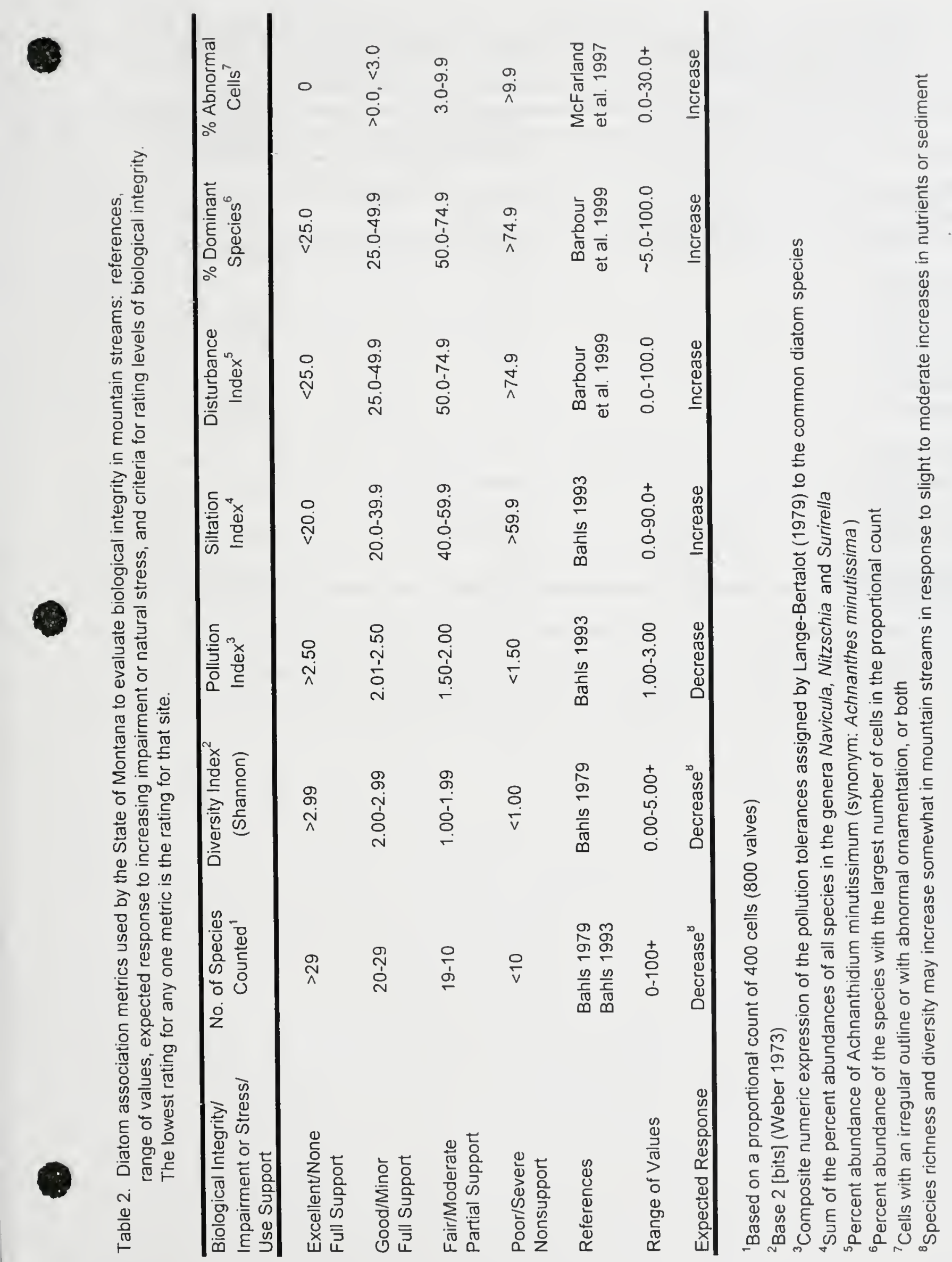


Table 3. Relative abundance of celis and ordinal rank by biovolume of diatoms (Division Bacillariophyta) and genera of non-diatom algae in periphyton samples collected from Jackson Creek, Jennies Fork, and Granite Creek in 2002.

\begin{tabular}{|c|c|c|c|}
\hline Taxa & $\begin{array}{c}\text { Jackson Creek } \\
\text { near mouth }\end{array}$ & $\begin{array}{c}\text { Jennies Fork } \\
\text { below ski parking }\end{array}$ & $\begin{array}{l}\text { Granite Creek } \\
\text { near mouth }\end{array}$ \\
\hline \multicolumn{4}{|l|}{ Cyanophyta } \\
\hline Nostoc & common $\left(3^{\text {rd }}\right)$ & & frequent $\left(3^{\text {rd }}\right)$ \\
\hline Oscillatoria & abundant $\left(1^{\text {st }}\right)$ & occasional $\left(3^{\text {rd }}\right)$ & occasional $\left(5^{\text {th }}\right)$ \\
\hline \multicolumn{4}{|l|}{ Rhodophyta } \\
\hline Audouinella & & & occasional $\left(6^{\text {th }}\right)$ \\
\hline \multicolumn{4}{|l|}{ Chlorophyta } \\
\hline Cladophora & & & abundant $\left(1^{\text {st }}\right)$ \\
\hline Closterium & & & common $\left(4^{\text {th }}\right)$ \\
\hline \multicolumn{4}{|l|}{ Chrysophyta } \\
\hline Hydrurus foetidus & & abundant $\left(1^{\text {st }}\right)$ & \\
\hline Bacillariophyta & frequent $\left(2^{\text {nd }}\right)$ & $\operatorname{common}\left(2^{\text {nd }}\right)$ & frequent $\left(2^{\text {nd }}\right)$ \\
\hline \# Non-Diatom Genera & 2 & 2 & 5 \\
\hline
\end{tabular}


Table 4. Percent abundance of major diatom species ${ }^{\dagger}$ and values of selected diatom association metrics for periphyton samples collected from Jackson Creek, Jennies Fork, and Granite Creek in 2002. Underlined values indicate minor stress; bold values indicate moderate stress; underlined and bold values indicate severe stress; all other values indicate no stress and full support of aquatic life uses when compared to criteria for mountain streams in Table 2. Stress may be natural or anthropogenic (see text).

\begin{tabular}{lcccc}
\hline \multicolumn{1}{c}{ Species/Metric } & PTC $^{2}$ & $\begin{array}{c}\text { Jackson Creek } \\
\text { near mouth }\end{array}$ & $\begin{array}{c}\text { Jennies Fork } \\
\text { below ski parking }\end{array}$ & $\begin{array}{c}\text { Granite Creek } \\
\text { near mouth }\end{array}$ \\
\hline Achnanthidium minutissimum & 3 & 10.82 & 34.43 & 3.11 \\
Cocconeis placentula & 3 & 1.16 & 0.98 & 20.81 \\
Fragilaria vaucheriae & 2 & 1.79 & 5.68 & 11.00 \\
Gomphonema rhombicum & 3 & 0.53 & & 8.49 \\
Navicula cryptotenella & 2 & 16.18 & 0.33 & 3.47 \\
Nitzschia linearis & 2 & 8.40 & 3.83 & 0.96 \\
Planothidium lanceolatum & 2 & 9.87 & 6.56 & 11.60 \\
Rhoicosphenia abbreviata & 3 & 4.52 & & 8.61 \\
Number of Species Counted & & & 59 & 48 \\
Shannon Species Diversity & & 4.43 & 4.09 & 4.18 \\
Pollution Index & & $\underline{2.39}$ & $\underline{2.44}$ & 2.53 \\
Siltation Index & 43.80 & $\underline{34.43}$ & 19.14 \\
Disturbance Index & 10.82 & $\underline{34.43}$ & 3.11 \\
Percent Dominant Species & 16.18 & $\underline{0.44}$ & 20.81 \\
Percent Abnormal Cells & $\underline{2.00}$ & & $\underline{0.12}$ \\
\end{tabular}

${ }^{1} \mathrm{~A}$ major diatom species accounts for $5.0 \%$ or more of the cells at one or more stations in a sample set.

${ }^{2}$ (Organic) Pollution Tolerance Class (Lange-Bertalot 1979): 1 = most tolerant; 2 = tolerant; 3 = sensitive. 
Table 5. Modal categories for selected ecological attributes of diatom species in Jackson Creek, Jennies Fork, and Granite Creek in 2002.

\begin{tabular}{|c|c|c|c|}
\hline Ecological Attribute & $\begin{array}{l}\text { Jackson Creek } \\
\text { near mouth }\end{array}$ & $\begin{array}{c}\text { Jennies Fork } \\
\text { below ski par'king }\end{array}$ & $\begin{array}{l}\text { Granite Creek } \\
\text { near mouth }\end{array}$ \\
\hline Motility ${ }^{1}$ & $\begin{array}{l}\text { Not } \\
\text { Motile }\end{array}$ & $\begin{array}{l}\text { Not } \\
\text { Motile }\end{array}$ & $\begin{array}{l}\text { Not } \\
\text { Motile }\end{array}$ \\
\hline $\mathrm{pH}^{2}$ & Alkaliphilous & Circumneutral & Alkaliphilous \\
\hline Salinity ${ }^{2}$ & $\begin{array}{l}\text { Fresh- } \\
\text { Brackish }\end{array}$ & $\begin{array}{l}\text { Fresh- } \\
\text { Brackish }\end{array}$ & $\begin{array}{l}\text { Fresh- } \\
\text { Brackish }\end{array}$ \\
\hline Nitrogen Uptake ${ }^{2}$ & $\begin{array}{l}\text { Autotrophs } \\
\text { (tolerate high } \\
\text { organics) }\end{array}$ & $\begin{array}{l}\text { Autotrophs } \\
\text { (tolerate high } \\
\text { organics) }\end{array}$ & $\begin{array}{l}\text { Autotrophs } \\
\text { (tolerate high } \\
\text { organics) }\end{array}$ \\
\hline Oxygen Demand ${ }^{2}$ & $\begin{array}{l}\text { Continuously High (31\%) } \\
\text { Moderate }(24 \%)\end{array}$ & $\begin{array}{c}\text { Continuously High (49\%) } \\
\text { Moderate }(23 \%)\end{array}$ & $\begin{array}{l}\text { Moderate }(47 \%) \\
\text { Fairly High }(21 \%)\end{array}$ \\
\hline Saprobity $^{2}$ & beta-Mesosaprobous & beta-Mesosaprobous & beta-Mesosaprobous \\
\hline Trophic State ${ }^{2}$ & Variable & Variable & Eutraphentic \\
\hline
\end{tabular}

${ }^{1}$ Dr. R. Jan Stevenson, Michigan State University, digital communication.

${ }^{2}$ Van Dam et al. 1994 